\title{
E-SERVICE COMPOSITION FOR DECISION SUPPORT, BASED ON MONITORING OF CONTAMINATION PROCESSES AND ANALYSIS OF WATER RESOURCE DATA
}

\author{
Dale DZEMYDIENE ${ }^{\mathrm{a}}$, Saulius MASKELIŪNAS ${ }^{\mathrm{b}}$, Arūnas MILIAUSKAS ${ }^{\mathrm{a}, \mathrm{b}}$, \\ Ramute NAUJIKIENE $\dot{a}^{a}$, Giedrè DZEMYDAITÉ ${ }^{c}$ \\ ${ }^{a}$ Business and Media School, Mykolas Romeris University, Ateities g. 20, \\ LT-08303 Vilnius, Lithuania \\ ${ }^{b}$ Institute of Mathematics and Informatics, Vilnius University, Akademijos g. 4, \\ LT-08663 Vilnius, Lithuania \\ ${ }^{c}$ Department of Economic Policy, Faculty of Economics, Vilnius University, Sauletekio al. 9, \\ LT-10222 Vilnius, Lithuania
}

Received 10 November 2014; accepted 31 May 2015

\begin{abstract}
Our research concerns the development of a unified coherent framework for evaluating water contamination processes and solving environment protection problems according to sustainable development requirements. The research investigations are made according to the requirements of the European Union (EU) Water Framework Directive and Sustainable Development Strategy. The article describes the decision support processes, based on integration of distributed data warehouses that are on the responsibility of different institutions. The Water Resource Management Information System became the kernel component of a decision support system. We analyse the possibilities of composing e-services in a semi-automatic way for decision support by analysing data processes in the water management sector. We would like to show the possibilities of integrating of data into a web portal from the distributed databases of the water management sector. The information infrastructure of e-service provision is constructed by ensuring the requirements of interoperability. The composition mechanisms of e-service are based on SOA, i.e. service-oriented architecture, and the Goal-Based Service Framework idea. The results are demonstrated on wastewater discharges from farms and household production into surface waters of Lithuanian districts during the period of 2003-2012 years. The water resource management domain specification is based on the goal-based service ontology.
\end{abstract}

Keywords: decision support system (DSS), e-service composition, Water Resource Management Information System (WRMIS), data warehouses.

JEL Classification: C88, Q25, Q56.

Corresponding author Dalè Dzemydienè

E-mail:daledz@mruni.eu 


\section{Introduction}

The aim of this study is to examine the information infrastructure for water resource planning and water treatment activities, to provide evaluation indicators and data storage arrays that measure the environmental and water pollution according to the requirements of sustainable development. The assessment of pollution situations, selecting the appropriate search parameters and methods for decision support that allow revealing the water and environmental contamination by effluents, is important in many research studies (Heringa et al. 2010; Ciegis et al. 2008; Junier, Mostert 2014; Lescot et al. 2013, Mardani et al. 2015).

It is important to monitor the environmental pollution and to carry out accounting of the ecological balance (Kaklauskas, Zavadskas 2007; Šliogerienè et al. 2009; Pearson et al. 2010). The studies reveal the requirements of sustainable development for wastewater and water treatment sector accounting activities; identify the existing problems that need to be addressed in order to ensure the quality of water and a clean environment (Junier, Mostert 2014; Simonovic 2008).

Environment protection consists of multiple components and make up a totality of requirements that can be presented as the standards of enterprise functioning, requirements of a healthy human environment, permission for functioning of contamination objects, pollution taxes, urban pollution treatments, etc. (Baltrenas, Kazlauskiene 2009; Burinskiene et al. 2003; Swanson et al. 2004; Dzemydaite, Galinienè 2013; Kaklauskas et al. 2009).

Water resources can be considered as an important and dynamically changing part of the environment protection domain with specific operatively displaying needs of representation in the decision support system (DSS) (Dzemydienè et al. 2008a). Additional means are integrated in the structure of DSS such as conceptual schemes, dataflow diagrams, and on-line management techniques for identifying the abnormal situations of pollution. The automatic provision of e-services requires the integration of databases into the complex infrastructure. A secondary data analysis was made in order to assess the surface water pollution.

Sustainability should not be excluded from both the quality of life and satisfaction of the main needs of nature. The main principles of sustainability are introduced in the decision-making processes by maintaining the possibilities to have a cleaner environment. The activities of large enterprises, institutions, and organizations should be based on a versatile responsibility of enterprises and stimulation to a higher efficiency of the cleaning equipment, paying more attention to the requirements of the sustainable development.

The methodology of design of this type decision support system is based on multi-layered architecture of databases of different public administration institutions such as Environment Information and Observation Network (EIONET), Joint Research Centre (JRC), Geological Survey (GS), Hydro-meteorological Service, Ministry of Environment (MoE), Marine Research Centre (MRC), etc. 


\section{Related works}

Developing and advanced countries in the European Union have to face different challenges of sustainable development; however, escalated use of natural resources and preservation of a clean environment remain priority problems (Giupponi 2007; Heringa et al. 2010). Already in the United Nations Conference on Environment and Development, Earth Summit 1992 in Rio de Janeiro, the sustainable development provisions were formulated: the Sustainable development Action Program for the implementation of Agenda 21 and Declaration. This set out the main principles of the sustainable development. The EU Sustainable Development Strategy was adopted in 2001, in Gothenburg (Sweden) by the European Council, stating that sustainable development is a long-term EU strategy to ensure a clean and healthy environment and better quality of life for present and future generations (European Commission 2001).

However, for example, while monitoring soil contamination-associated processes in the EU Member States, there can be seen about 250,000 possible sources of polluting activities. As shown in the national accounts of the EU countries contaminants, most commonly found in the soil, are heavy metals and mineral oils. Mineral oil and chlorinated hydrocarbons are also commonly found in contaminated ground water. A large part of the used cleaning costs, about $35 \%$, came from the public sector budget. It will take decades to clean up the legacy of pollution that has already occurred; EU countries pay considerable environmental pollution charges.

The implementation of sustainable development requirements is indispensable for accelerating the social progress and improving the environment: the social policies that promote balanced and sustainable economic growth and environmental protection are cost-effective. One of the key objectives of this strategy is "ensuring that the growth of the economy of natural resources and environmental pollution to grow much more slowly than the economy as a whole, or to cease grown" (European Commission 2010). It is necessary to focus on the scientific progress, knowledge and innovative implementation of environmental measures that would allow us to install the latest, more environment-friendly technologies.

The indicators of the analysis are very important factors that could enable a better assessment of water pollution problems in the Baltic Sea region. Scientific research works in this area are aimed to assess the requirements of sustainable development opportunities for wastewater sector activities, proposing measures for the provision of information on the development of infrastructure (Argenta et al. 2009; McIntosh et al. 2011; Dzemydienè et al. 2008a, 2008b; Dzemydiene, Maskeliunas 2011; Saarenmaa 2002; Kaklauskas et al. 2015). The articles discuss the problems associated with the evaluation of the situation of environmental pollution, the appropriate parameters that allow disclosure of water contamination by effluents in the Baltic Sea region.

We would like to mention the related works in the area of development of the decision support systems proposed by J. Mysiak, C. Giupponi, and P. Rosato (Mysiak et al. 2005) created on the background of the MULINO project for water resources management, as well as the work of M. Pocha (Pocha et al. 2004) in which they proposed the methodology of designing environmental DSS. J. den Boer, E. den Boer, J. Jager proposed the decision 
support tool for waste management (den Boer et al. 2007; Ryu et al. 2009). Development of district's analysis, such as the Lithuanian regions, based on sustainable development requirements and risks analysis, is provided in the research study (Dzemydaite, Galiniene 2013). Regional infrastructure disparities are evaluated by using spatial data envelopment analysis method (Galinienè, Dzemydaite 2012). The infrastructure of DSS for good transportation monitoring were proposed in (Dzemydiene, Dzindzalieta 2012; Andziulis et al. 2012). The system of intellectual services providing for the closed apartment microclimate monitoring and ecological management is proposed by (Bielskis et al. 2011).

Most of the existing environmental information systems have evolved during a long period. Therefore, most of the systems are found to be both heterogeneous and scattered without much possibility of using data and information in an integrated manner (Bhargavaa et al. 2007; Maesa et al. 2012; Matthiesa et al. 2007; Pearson et al. 2010).

Our research study is aimed to analyse the activities of enterprises, institutions, and organizations according to sustainability requirements. The on-line techniques allow us to access the distributed data warehouses for providing e-services. Multi-aspect analysis techniques allow us to identify the water quality situation in rivers, lakes, marine and ground water bodies, and to evaluate the concrete point sources of emissions. The high data storing, analysis, and reporting requirements are used. For assurance of interoperability, the XML, SOAP, and HTTP protocols are used.

Originality and the value of our research are based on the development of the Water resource management information system (WRMIS) and provision of e-services on-line. That facilitates the access to data for the relevant institutions and public e-services. WRMIS helps control easy dataflow between the institutions and service providers. The structure of the kernel part of the WRMIS was presented in (Dzemydienè et al. 2008b; Dzemydiene, Maskeliunas 2011).

The purpose of this work is to provide e-services by unifying the structures of distributed information systems, while estimating proposals how to simulate situations, intellectualize the estimation of environment pollution by evaluating the wastewater emission from contamination objects. A multi-componential structure of information systems belonging to different institutions is proposed. The examples of e-service compositions by using workflow structures are described. The interoperable infrastructure of unified data warehouses for on-line e-services is designed and possibilities of dataflow between different institutions of public administration as well as of multi-aspect data analysis according to the efficiency of wastewater treatment in districts of Lithuania are presented.

\section{Components of interoperable data warehouses for evaluating water contamination processes}

The countries located in the Baltic Sea region are aimed at making cleaner the ground and surface water in rivers, lakes, the Kuršiai Lagoon, and the Baltic Sea, and to maintain a wide variety of ecosystems, to make the surface water bodies cleaner, possible for recreational purposes, and to supply all residents of the country with safe and high quality drinking water. 
It is important to timely solve the following tasks:

- To reduce the pool pollution by 810 tons of nitrogen, 85 tons of phosphorus, the biochemical oxygen demand within 7 days - by 1050 tons, compared to 2004;

- To reduce diffuse pollution with nitrogen and phosphorus;

- To ensure that all economic activities were organised so that the pollutants which are hazardous to the environment and human health would not get into surface and ground water (Government of the Republic of Lithuania, Resolution No. 1247, 200909-16).

To achieve these objectives, it is important to reduce the surface and ground water pollution with the help of the state, local, private, and/or EU structural support funds.

We have to evaluate the situation continually, taking into account the usage of water resources, wastewater effluxes, waste utilization, contamination levels, protection efficiency, etc. in different regions and districts. To this end, the decision support should be integrated with data warehouses.

We propose the principal schema of workflows among the main system components (Fig. 1). An expected future of data flows in EU can be expressed as interconnection between decision makers of public institutions and distributed databases (Fig. 1).

The main flows of data and information are between such institutions as:

- European Environment Information and Observation Network (EIONET);

- Statistical Office of the European Communities (EuroStat);

- Directorate-General of EC and National Reference Centres;

- National Focal Point;

- Organisation for Economic Co-operation and Development (OECD);

- Infrastructure of EIONET for supporting and improving data and information flows (ReportNet);

- United Nations Environment Programme (UNEP);

- Other institutions that can dynamically connect to this system.

Data flows among distributed databases have caused the following problems of situation management for support of public e-services:

- a strict division between ground, marine, and fresh water influences the problems of the integrated strategic management of the whole water sector;

- a high amount of data, available in the different institutions, causes the problem of interoperability among distributed databases;

- a high degree of dedication and specialisation has influence on the special requirements and needs of data security and publicity;

- there is no strong tradition in the coordination and sharing of data and knowledge on the Internet.

The interface between data warehouses and web applications is developed using web service development tools, based on XML, SOAP, HTTP protocols. The meta-models are used for a unified networking of data warehouses. 


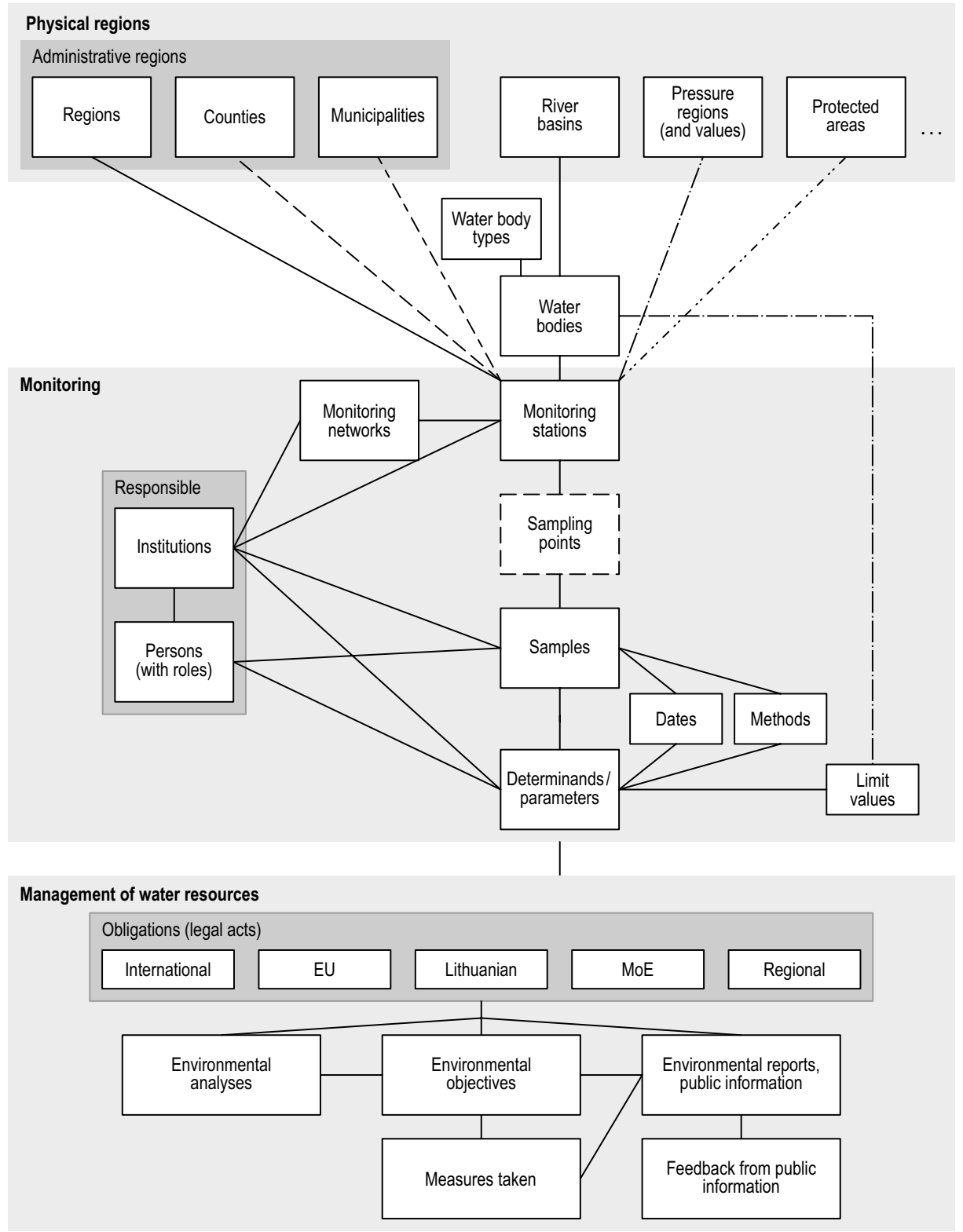

Fig. 1. The scheme of water monitoring and analysis

\section{Provision of water protection information, based on the semi-automatic e-service composition}

The advisory system is aimed at assisting processes that include the situation recognition, planning, and control processes in the environment protection area. The infrastructure of information systems is closely connected to e-service providers. The structures of data 
warehouses are integrated with knowledge modelling techniques and the revealed information is applied in the decision support. The types of services are divided according to workplace types and their needs for different specialists - data analysts. A software developer is not involved here; information is provided via e-services.

The system uses a composition of several services based on user requirements and contextual information recognition.

A composition of several services depends on the requirements provided by the end-users. In the composition of e-services artificial intelligence (AI) planning tools are used based or goal-driven approach applied in the work of (Portchelvi et al. 2012). However, the end-user should have some software engineering knowledge, in order to define the planning problem in a format of the AI planner. We propose SHOP2 as a tool developed for this purpose.

The Goal-Based Service Framework proposed by da Silva Santos et al. (2009) is used in our approach. The water resource management domain specification is created based on the Goal-Based Service Ontology.

An e-service composition can be treated as a planning problem, i.e. the performance of the required services in correct order. This order (execution plan) can be determined using artificial intelligence planning methods and tools. We have chosen SHOP2 - a hierarchical task network (HTN) planner (Nau et al. 2003) for plan generation.

An input planning problem and planning domain definitions are presented in a format similar to the Planning Domain Definition Language, and the abstract workflow is produced in SHOP2 planner. The composition requirements, based on the concepts of water resource management domain specification are presented by users. The solution distinguishes various types and levels of goals. E.g., some user can provide the goal KeepWasteWaterContaminationAtSafeLevel; this goal can be decomposed to lower level goals, i.e., TrackContaminationLevels, ReportIncreasedContaminationLevels, which, in their turn, can be decomposed further, too (see Fig. 2).

Each task helps achieve the goal, and can be an AtomicTask or a ComplexTask. Tasks are mapped directly to a HTN planning domain. The AtomicTask is mapped to an operator in HTN (HTNOperator), and the ComplextTask corresponds to CompoundHTNTask. The CompoundHTNTask uses the HTNMethod for task decomposition (see Fig. 3).

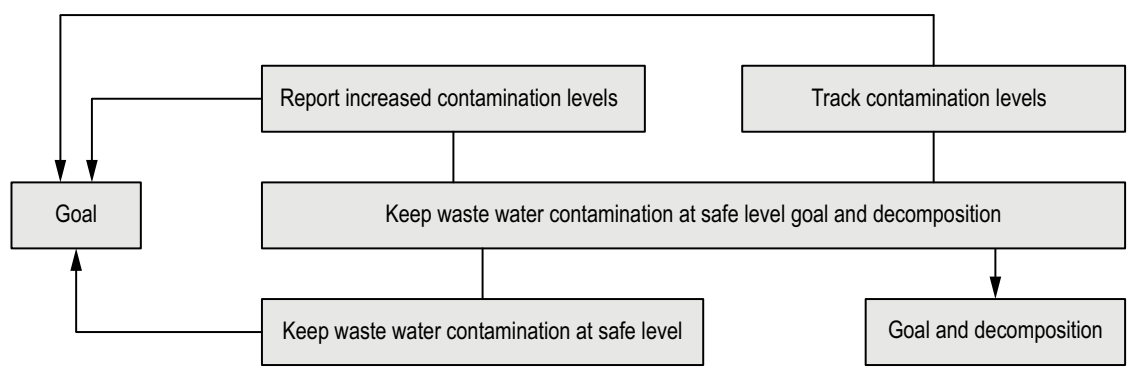

Fig. 2. An example of goal decomposition 
If the knowledge base conforms to the presented model, the goals are decomposed into tasks and mapped to the HTN planning domain. The tasks that are members of ComputationalServiceTask are performed by a ComputationalService (i.e., e-service) in the e-service composition scenario. So, the system transforms the planner's results into e-service execution calls.

The scheme of relationships between the entities of the e-service composition system is presented in Figure 4. The scheme represents entities of dataflow, workflow, and collaboration processes, as well as surface water quality monitoring processes.

We consider the activities of enterprises, firms, and organizations, i.e. the main stationary objects, to estimate pollution of water bodies. In addition, the objects must give reports according to their activities pursued and in line with the statistical accountability forms.

The water resource management information system is a core of the on-line working decision support system. WRMIS warrants the access to the information that is stored in specialised distributed data warehouses, and both the point sources (emissions) and the surface water quality in rivers, lakes, and ground water are estimated.

The use of WRMIS allows gaining the following advantages:

- distributed databases are maintained by experts in the places of data collection;

- the data are shared via the Internet, without the need for data replication and redundancy;

- water resource data are integrated with maps, supporting the water quality and point sources data management, analysis, and reporting.

The e-service interconnections of WRMIS are presented in Figure 5. The European Environment Information and Observation Network is responsible for the ReportNet infrastructure to support and improve data and information flows. The Joint Research Centres of EU countries are accumulating the surface water data in the data warehouses. All the countries are collecting data on ground, surface, marine water quality, and point sources.

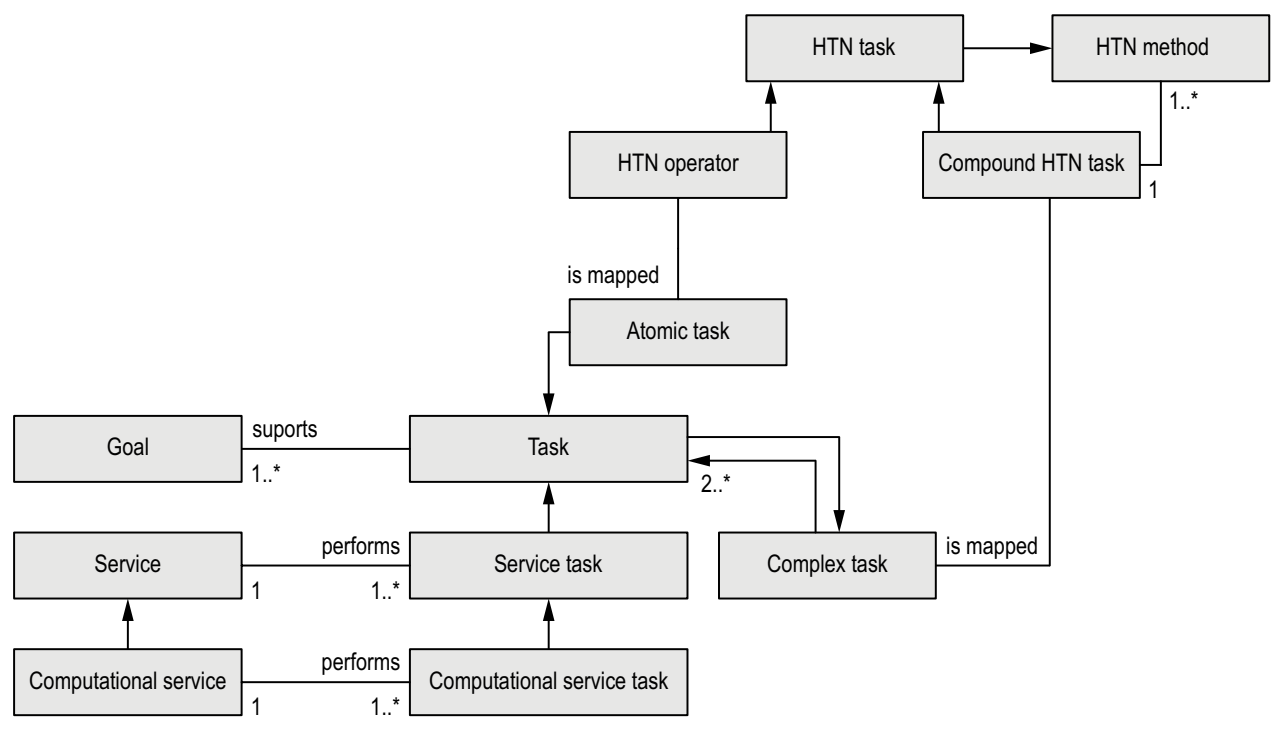

Fig. 3. Task decomposition and the relationship to goals and services 


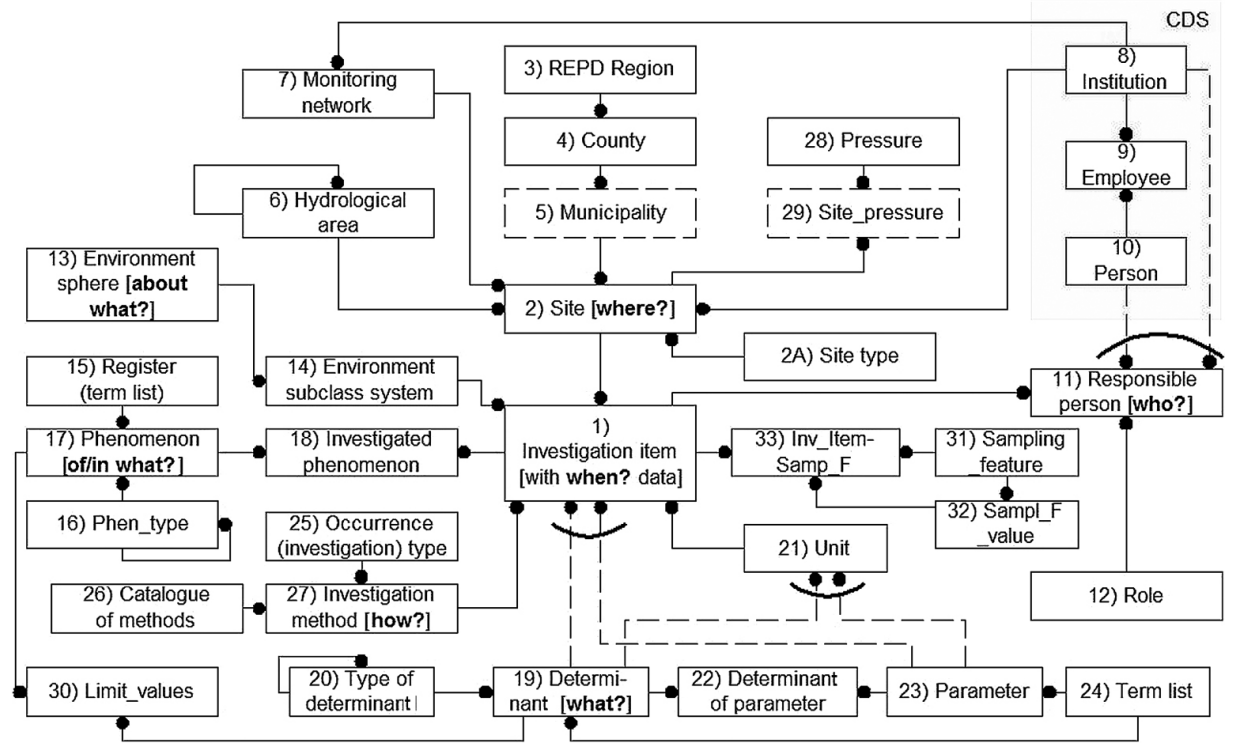

Fig. 4. Relationships between entities of the e-service composition system

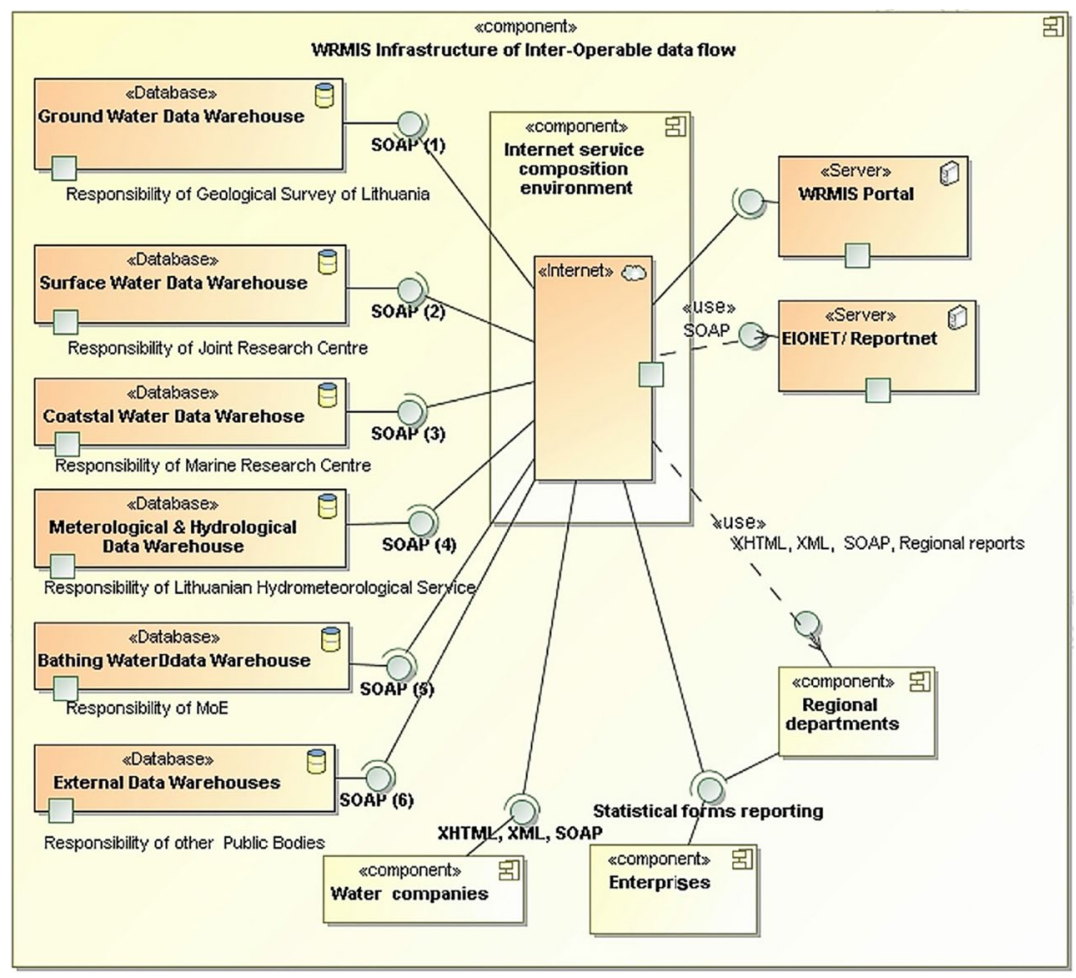

Fig. 5. The scheme of WRMIS inter-connections of main databases and portal 
The main institutions such as the Geological Survey of Lithuania, Lithuanian Hydro-meteorological Service, Ministry of Environment of the Republic of Lithuania, and the Marine Research Centre are responsible for collecting, maintaining and providing such data in Lithuania. WRMIS is an infrastructure that combines and integrates multi-dimensional water resource information.

A dynamical change of values of the observed parameters is possible, depending on events occurring. In addition, solution of different problems can cause interferences.

\section{Results of multi-aspect analysis of environmental data}

For illustration of the working WRMIS system we present the information provided by one type of windows (Fig. 6). Applying the multi-aspect analysis techniques to the data warehouses, we get the information about the usage of water resources and contamination results according to the concrete geographical position a water resource (Longitude and Latitude coordinates), time, and the means of concrete observable parameters during the monitoring process.

The view of parameters that can be displayed is composed according to the Goal-based decomposition and can vary due to the temperature of water, $\mathrm{pH}$, concentrations of chemical materials, salt in a water body, etc. The answers are composed into the e-services, and can be presented in tables (see Fig. 6) or graphs.

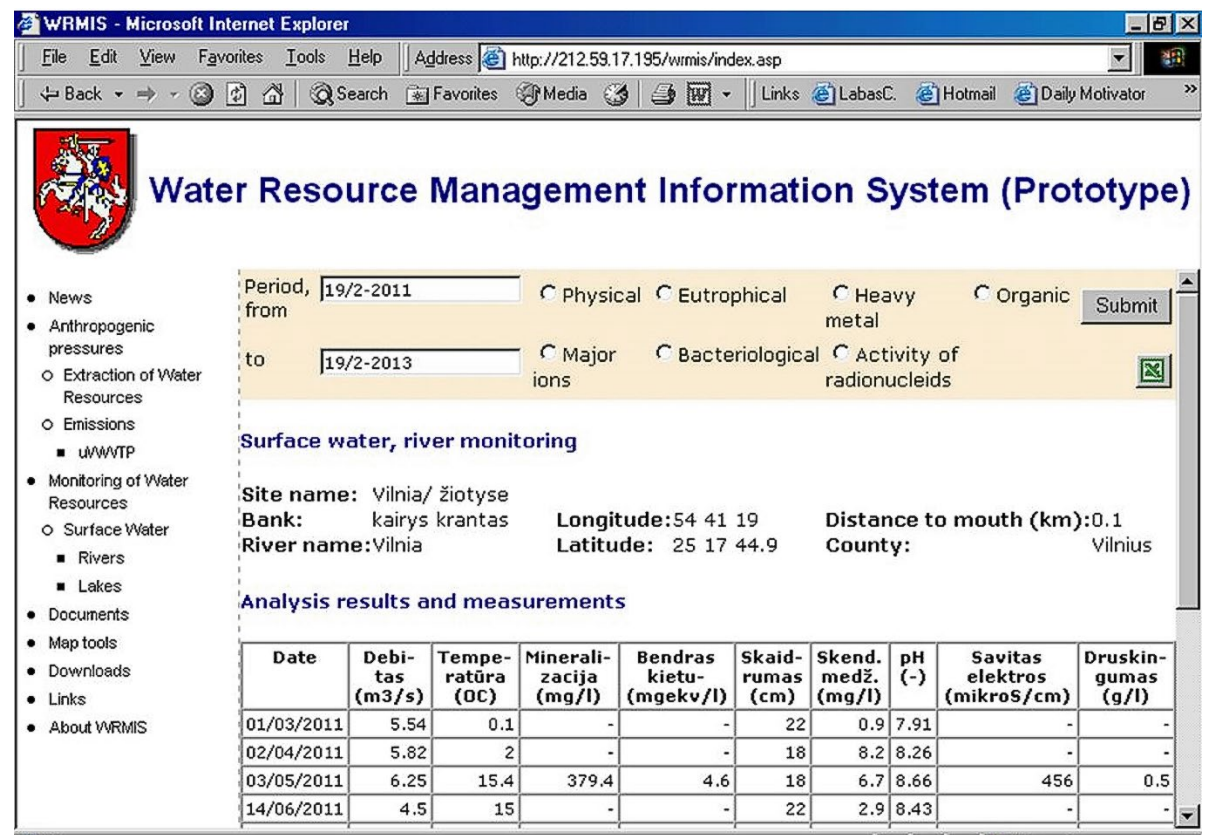

Fig. 6. WRMIS water contamination data view for the decision support 
The results can be displayed, e.g., by wastewater discharges from farms and household production into the surface waters in the Lithuanian districts. The illustration of graphical presentation of dynamic results of wastewater efflux from farms and household production in 2003-2012 is presented in Figure 7.

The results of analysing data dynamics - the wastewater which was treated to normal level in Lithuania during 2003-2012 year period is presented in Figure 8.

The results of the analysis of insufficiently treated wastewaters released into surface waters in the districts of Lithuania in 2011-2012 are presented in Figure 9.

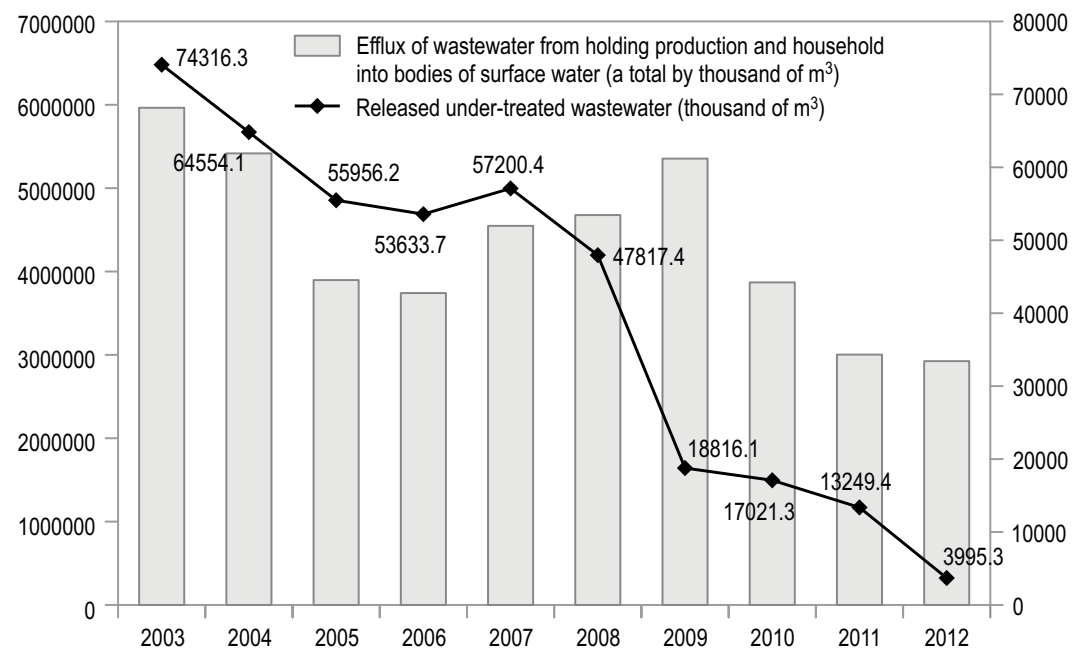

Fig. 7. The wastewater discharges from farms and household production into surface waters in the districts of Lithuania during 2003-2012 years

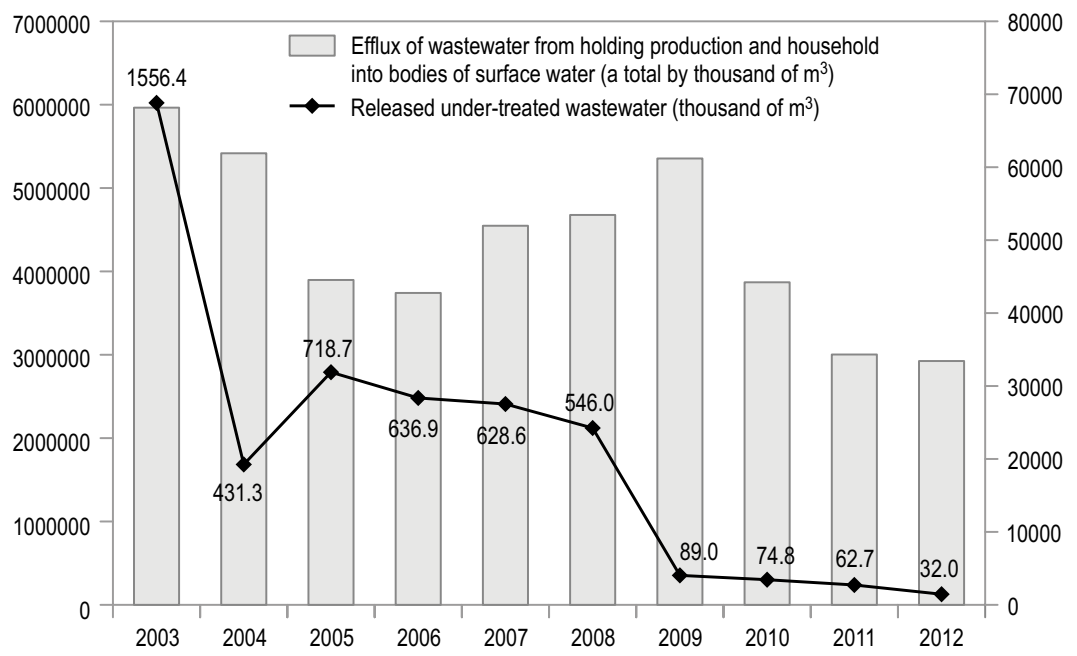

Fig. 8 . The results of the analysis on the normally treated wastewaters releases into surface waters in the districts of Lithuania during the period 2003-2012 


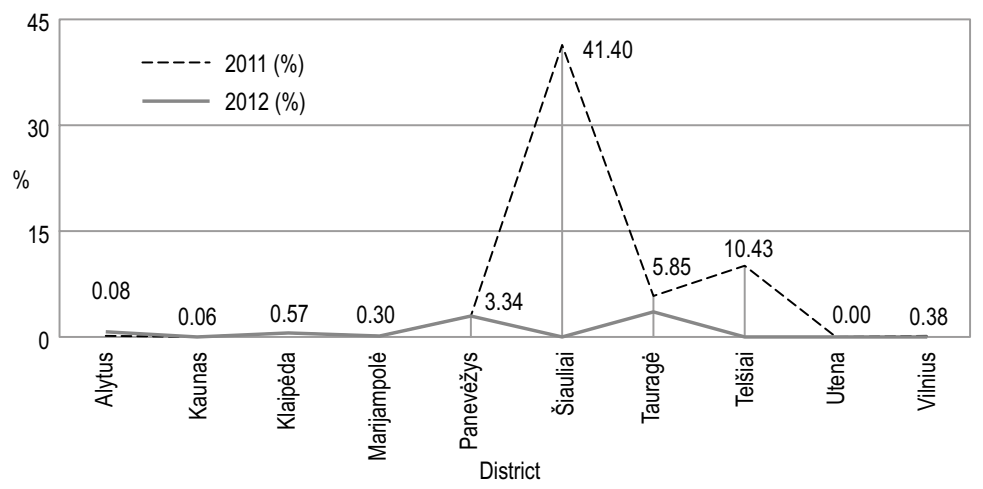

Fig. 9. Insufficiently treated wastewaters releases into surface waters in the districts of Lithuania during the period 2011-2012

\section{Conclusions}

The approach for representing interconnections of the Water resource management information system and possibilities of semi-automated e-service composition are presented. The interoperable data warehouses are interconnected in a coherent framework. The European Environment Information and Observation Network is responsible for ReportNet, i.e. the infrastructure for supporting and improving data and information flows. The Joint Research Centres accumulate all information on the surface water in data warehouses of the EU countries. All the countries provide data about specific geological, hydro and meteorological data changes. The Geological Survey of Lithuania, Lithuanian Hydrometeorological Service, Ministry of Environment of the Republic of Lithuania, and Marine Research Centre are responsible for providing and maintaining such data in data warehouses in Lithuania. WRMIS combines multi-dimensional infrastructure of information. The components of decision support information infrastructure for evaluating the wastewater contamination are described.

The representation of dynamical aspects shows the dynamics of observable processes. The monitoring subsystems are as agents working in parallel, while the temporal information window organizes the communication. The multiple objective decision making deals with the analysis of information obtained from the static sub-model taking into account all possible measurement points revealed in the temporal window of dynamically changed information.

The means of enterprise development should be based on a versatile responsibility of enterprises and stimulation of efficiency, paying even more attention to the requirements of sustainable development and to the issues of environment protection: strategic and tactical planning and control, estimation of economic-social balance, application of information technologies and constant check systems, as well as to the legal regulation effect. 


\section{Acknowledgements}

The authors thank the European Environment Information and Observation Network, Joint Research Centre of EU, and Lithuanian Environment Protection Agency for information support and collaboration possibilities in the Water Resource Management Information System development in the project "Transposition of the EU Water Framework Directive in Lithuania”, and Danish co-operation for the Environment in Eastern Europe.

\section{References}

Andziulis, A.; Jakovlev, S.; Adomaitis, D.; Dzemydiené, D. 2012. Integration of mobile control systems into intermodal container transportation management, Transport 27(1): 40-48. http://dx.doi.org/10.3846/16484142.2012.665206

Argenta, R. M.; Perraudb, J.-M.; Rahmanb, J. M.; Graysona, R. B.; Podgerb, G. M. 2009. A new approach to water quality modelling and environmental decision support systems, Environmental Modelling \& Software 24(7): 809-818. http://dx.doi.org/10.1016/j.envsoft.2008.12.010

Baltrenas, P.; Kazlauskiene, A. 2009. Sustainable ecological development reducing negative effects of road maintenance salts, Technological Economical Development of Economy 15(1): 178-188. http://dx.doi.org/10.3846/1392-8619.2009.15.178-188

Bhargavaa, H. K.; Powerb, D. J.; Sun, D. 2007. Progress in Web-based decision support technologies, Decision Support Systems [Special Issue Clusters] 43(4): 1083-1095. http://dx.doi.org/10.1016/j.dss.2005.07.002

Bielskis, A. A.; Andziulis, A.; Ramašauskas, O.; Guseinovienè, E.; Dzemydienė, D.; Gricius, G. 2011. Multi-agent based e-social care support system for inhabitancies of a smart eco-social apartmen, Electronics and Electrical Engineering 1(107): 11-14.

den Boer, J.; den Boer, E.; Jager, J. 2007. LCA-IWM: a decision support tool for sustainability assessment of waste management systems, Waste Management 27(8): 1032-1045.

http://dx.doi.org/10.1016/j.wasman.2007.02.022

Burinskiene, M.; Dzemydiene, D.; Rudzkiene, V. 2003. An approach for recognition of significant factors for sustainable development strategies, in H. Pranevicius, E. Zavadskas, B. Rapp (Eds.). Proc. of International Conference "Modelling and Simulation of Business Systems". Kaunas: Technology, 90-96.

Ciegis, R.; Streimikiene, D.; Zavadskas, E. K. 2008. The use of the environmental Kuznets curve: environmental and economic implications, International Journal of Environment and Pollution 33(2-3): 313-335. http://dx.doi.org/10.1504/IJEP.2008.019401

Dzemydaitè, G.; Galinienè, B. 2013. Evaluation of regional efficiency disparities using efficient frontier analysis, Journal Economics 92(4): 21-36.

Dzemydiene, D.; Dzindzalieta, R. 2012. Multi-Layered architecture of decision support system for monitoring of dangerous good transportation, in A. Čaplinskas, G. Dzemyda, A. Lupeikienè, O. Vasilecas (Eds.). Databases and Information Systems, Tenth International Baltic Conference on Databases and Information Systems (Baltic DB\&IS'2012). Local Proceedings, Materials of Doctoral Consorcium, 8-11 July 2012, Vilnius, Lithuania. Vilnius: Žara, 128-141.

Dzemydiene, D.; Maskeliunas, S. 2011. Development of multi-componential decision support system in dynamically changing application domain of environment protection, in C. Jao (Ed.). Efficient decision support systems - practice and challenges from current to future. InTech, 405-422. http://dx.doi.org/10.5772/20143 
Dzemydienè, D.; Maskeliūnas, S.; Dzemyda, I. 2008a. Interoperability of information system components for monitoring of sewage and intelligent analysis of water resources, Technological and Economic Development of Economy 14(3): 260-278.

Dzemydienè, D.; Maskeliūnas, S.; Jacobsen, K. 2008b. Sustainable management of water resources based on web services and distributed data warehouses, Technological and Economic Development of Economy 14(1): 38-50.

European Commission. 2010. Europe 2020: a European strategy for smart, sustainable and inclusive growth [online], [cited 05 May 2015]. Available from Internet: http://ec.europa.eu/eu2020/pdf/ COMPLET\%20EN\%20BARROSO\%20\%20\%20007\%20-\%20Europe\%202020\%20-\%20EN\%20version.pdf

European Commission. 2001. Environment 2010: our future, our choice [online]. The Sixth EU Environment Action Programme 2001-2010 [cited 05 May 2015]. 12 p. Available from Internet: http:// ec.europa.eu/environment/archives/wssd/pdf/ourfuture_ourchoice.pdf

Galiniené, B.; Dzemydaite, G. 2012. Spatial data envelopment analysis method for the evaluation of regional infrastructure disparities, Social Technologies 2(2): 390-403.

Government of the Republic of Lithuania. 2009. Resolution No 1247 of 16 September, 2009. Amending Resolution No 1160 of the Government of the Republic of Lithuania of 11 September 2003 on the Approval and Implementation of the National Strategy for Sustainable Development [online], [cited 05 May 2015]. Available from Internet: http://www.am.lt/VI/en/VI/index.php\#a/297

Giupponi, C. 2007. Decision support systems for implementing the European water framework directive: the MULINO approach, Environmental Modelling \& Software 22(2): 248-258. http://dx.doi.org/10.1016/j.envsoft.2005.07.024

Heringa, D.; Borjab, A.; Carstensenc, J.; Carvalhod, L.; Elliotte, M.; Felda, Ch. K.; Heiskanenf, A.-S.; Johnsong, R. K.; Moeh, J.; Ponti, D.; Solheimh, A. L.; van de Bund, W. 2010. The European Water Framework Directive at the age of 10: a critical review of the achievements with recommendations for the future, Science of The Total Environment 408(19): 4007-4019.

http://dx.doi.org/10.1016/j.scitotenv.2010.05.031

Junier, S.; Mostert, E. 2014. A decision support system for the implementation of the Water Framework Directive in the Netherlands: process, validity and useful information, Environmental Science \& Policy 40: 49-56. http://dx.doi.org/10.1016/j.envsci.2014.04.004

Kaklauskas, A.; Kuzminske, A.; Zavadskas, E. K.; Daniunas, A.; Kaklauskas, G.; Seniut, M.; Raistenskis, J.; Safonov, A.; Kliukas, R.; Juozapaitis, A.; Radzeviciene, A.; Cerkauskiene, R. 2015. Affective tutoring system for built environment management, Computers \& Education 82: 202-216. http://dx.doi.org/10.1016/j.compedu.2014.11.016

Kaklauskas, A.; Zavadskas, E. K.; Šaparauskas, J. 2009. Conceptual modelling of sustainable Vilnius development, Technological and Economic Development of Economy 15(1): 154-177. http://dx.doi.org/10.3846/1392-8619.2009.15.154-177

Kaklauskas, A.; Zavadskas, E. K. 2007. Decision support system for innovation with a special emphasis on pollution, International Journal of Environment and Pollution 30(3-4): 518-528. http://dx.doi.org/10.1504/IJEP.2007.014826

Lescot, J.-M.; Bordenave, P.; Petit, K.; Leccia, O. 2013. A spatially-distributed cost-effectiveness analysis framework for controlling water pollution, Environmental Modelling \& Software 41: 107-122. http://dx.doi.org/10.1016/j.envsoft.2012.10.008

Maesa, J.; Egoha, B.; Willemena, L.; Liquetea, C.; Vihervaarab, P.; Schägnera, J. P.; Grizzettic, B.; Drakoua, E. G.; Nottea, A. L.; Zuliana, G.; Bouraouia, F.; Paracchinia, M. L.; Braatd, L.; Bidoglioa, G. 2012. Mapping ecosystem services for policy support and decision making in the European Union, Ecosystem Services 1(1): 31-39. http://dx.doi.org/10.1016/j.ecoser.2012.06.004 
Mardani, A.; Jusoh, A.; Zavadskas, E. K. 2015. Fuzzy multiple criteria decision-making techniques and applications - two decades review from 1994 to 2014, Expert Systems with Applications 42: 4126-4148. http://dx.doi.org/10.1016/j.eswa.2015.01.003

Matthiesa, M.; Giupponi, C.; Ostendorf, B. 2007. Environmental decision support systems: current issues, methods and tools, Environmental Modelling \& Software 22(2): 123-127. http://dx.doi.org/10.1016/j.envsoft.2005.09.005

McIntosh, B. S.; Ascough, J. C.; Tweryd, M.; Chewe, J.; Elmahdif, A.; Haaseg, D.; Harouh, J. J.; Heptingi, D.; Cuddyj, S.; Jakemanj, A. J.; Chenj, S.; Kassahunk, A.; Lautenbachg, S.; Matthewsl, K.; Merrittj, W.; Quinnm, N. W. T.; Rodriguez-Rodan, I.; Siebero, S.; Stavengap, M.; Sulisq, A.; Ticehurstj, J.; Volkg, M.; Wrobelr, M.; van Deldens, H.; El-Sawahj, S.; Rizzoliu, A.; Voinovv, A. 2011. Environmental decision support systems (EDSS) development - challenges and best practices, Environmental Modelling \& Software 26(12): 1389-1402. http://dx.doi.org/10.1016/j.envsoft.2011.09.009

Mysiak, J.; Giupponi, C.; Rosato, P. 2005. Towards the development of a decision support system for water resource management, Environmental Modelling \& Software 20(2): 203-214. http://dx.doi.org/10.1016/j.envsoft.2003.12.019

Nau, D. S.; Au, T. C.; Ilghami, O.; Kuter, U.; Murdock, J. W.; Wu, D.; Yaman, F. 2003. SHOP2: an HTN planning system, Journal of Artificial Intelligence Research 20: 379-404.

Pearson, L. J.; Coggan, A.; Proctor, W.; Smith, T. F. 2010. A sustainable decision support framework for urban water management, Water Resources Management 24(2): 363-376. http://dx.doi.org/10.1007/s11269-009-9450-1

Pocha, M.; Comasa, J.; Rodríguez-Rodaa, I.; Sànchez-Marrèb, M.; Cortés, U. 2004. Designing and building real environmental decision support systems, Environmental Modelling \& Software 19(9): 857-873. http://dx.doi.org/10.1016/j.envsoft.2003.03.007

Portchelvi, V.; Prasanna Venkatesan, V.; Shanmugasundaram, G. 2012. a study on composition goal in automated web services composition approaches, International Journal of Computer Applications 55(11): 4-8.

Ryu, J. H.; Palmer, R. N.; Jeong, S.; Lee, J. H.; Kim, Y.-O. 2009. Sustainable water resources management in a conflict resolution framework, JAWRA Journal of the American Water Resources Association 45(2): 485-499. http://dx.doi.org/10.1111/j.1752-1688.2009.00304.x

Saarenmaa, H. 2002. Reportnet: development of common tools and a shared information infrastructure for the European Environmental Information System. 2nd ed. NFP/EIONET Group Meeting paper.

da Silva Santos, L. B.; Guizzardi, G.; Guizzardi, R. S. S.; da Silva, E. G., Pires, L. F.; van Sinderen, M. 2009. GSO: designing a well-founded service ontology to support dynamic service discovery and composition, in 13th Enterprise Distributed Object Computing Conference Workshops, EDOCW, 1-4 September 2009, Auckland, New Zealand, 35-44.

Simonovic, S. P. 2008. Managing water resources: methods and tools for a system approach. UNESCO. $680 \mathrm{p}$.

Swanson, D. A.; Pintér, L.; Bregha, F.; Volkery, A.; Jacob, K. 2004. National strategies for sustainable development: challenges, approaches and innovations in strategic and co-ordination actions. IISD, 1-71.

Šliogeriené, J.; Kaklauskas, A.; Zavadskas, E. K.; Bivainis, J.; Seniut, M. 2009. Environment factors of energy companies and their effect on value: analysis model and applied method, Technological and Economic Development of Economy 15(3): 490-521.

http://dx.doi.org/10.3846/1392-8619.2009.15.490-521 
Dalè DZEMYDIENĖ is full professor at the Business and Media School of Mykolas Romeris University (Lithuania) and she is the scientific supervisor of doctoral studies in informatics engineering of Vilnius University. She holds a diploma with honour of applied mathematics in specialization of software engineering (1980), Doctor (PhD) in the field of mathematics - informatics (1995), defended habilitation doctor procedure in 2004. She published over hundred scientific research articles, two manual books and one monograph. She is organizer of international conferences on the data bases and information systems, international doctoral consortiums. She is a member of the Lithuanian Operation Research Association (LITORS), Lithuanian Computer Society, participates in the Council and in the sections of Artificial Intelligence, and Legal informatics. Her research interests include artificial intelligence methods, knowledge representation and decision support systems, research on sustainable development processes, e-service development.

Saulius MAKELIŨNAS is researcher at the Software Engineering Department in the Institute of Mathematics and Informatics of Vilnius University in Vilnius, Lithuania. He defended the diploma in engineering and system-technical sciences at the Kaunas University of Technology (1984); Doctor $(\mathrm{PhD})$ in informatics sciences (1996). He was co author and the system analyst of the projects "Governmental administrative information system VADIS" (1996-98), "Long-term assistance on information and reporting, information management programme" (2000-01), "Transposition of the EU Water Framework Directive and Elaboration of a National Strategy for the Management of Water Resources in Lithuania" (2002), "Implementation of the EU Water Framework Directive, Lithuania, Meeting 2006 deadlines" (2003-04); task leader of the project "Lithuania - RTD Technological Audit: A complex study of ICT RTD potential in Lithuania" (2009-10), expert of the projects "Creation of specialised application 'eMentorius' for personalized pedagogical e-consultations, applying adaptive models of process semantics and personalised semantic search methods" (2011-12), "The National Open Access Data Archive of Scientific Information (MIDAS)" (2012-2015). He is an author of about 50 research articles. His research interests: information and knowledge-based systems, ontological engineering, semantic web, web services, scientometrics, knowledge management.

Arūnas MILIAUSKAS is doctoral student of technological sciences in the field of informatics engineering at the Software Engineering Department of the Institute of Mathematics and Informatics at Vilnius University (Lithuania) and lecturer at the Business and Media School of Mykolas Romeris University. His research interests: software development, artificial intelligence methods, e-service composition tools.

Ramutė NAUJIKIENE is assoc. professor, doctor at the Business and Media School of Mykolas Romeris University (Lithuania). She holds a diploma of specialty of engineering in physics at $1971, \mathrm{PhD}$ in the field of social sciences with specialization of management and administration in 2012. The qualification courses in software programming and database applications. She published about 50 scientific research articles and 4 manual books with co-authors. Her research interests include: information management, databases, e-public service development.

Giedrè DZEMYDAITE் is doctoral student of social sciences in the field of economics. She holds a diploma of Master of economics at Vilnius University and she is working as the lecturer at the Department of Economics Policy of Vilnius University (Lithuania). Her research interests include: innovations and economic development methods of regional development, indicators of sustainability. 